Scientific Review - Engineering and Environmental Sciences (2018), 27 (4), 425-437

Sci. Rev. Eng. Env. Sci. (2018), 27 (4)

Przegląd Naukowy - Inżynieria i Kształtowanie Środowiska (2018), 27 (4), 425-437

Prz. Nauk. Inż. Kszt. Środ. (2018), 27 (4)

http://iks.pn.sggw.pl

DOI 10.22630/PNIKS.2018.27.4.41

Raid Mahmood FAISAL, Mohammed Fakhraldeen AHMED

College of Environmental Sciences and Technology, Mosul University

\title{
GIS and AHP based modeling for landfill site selection (case study: west side of Mosul city)
}

Key words: GIS, Solid waste landfill, AHP, optimality

\section{Introduction}

In spite of the municipal management efforts, large quantities of solid waste accumulate each day in Mosul city and causes a real problem. The reasons of this problem are: firstly, most of collection vehicles became out of service as a result of aging; secondly, the huge people migration from villages to the city; thirdly, most of current dumps were randomly selected within the city boundaries; finally, the absence of real effort to use scientific plans to select a suitable landfill site complying with national standards. For all these reasons, a planned municipal landfill for Mosul city becomes enormously needed.

There are few researches to select the optimal landfill site within Iraq, for example, Chabuk, Al-Ansari, Hassain and Knutsson (2017) attempted to determine a suitable landfill site for Al-Musayiab Qadhaa, Babylon. They used two methods to derive weights for criterion map on GIS, AHP and simple additive weighting (SAW). Two of candidates' sites were identified for landfill site selection in the final map.

Worldwide attempts for landfill site selection were numerous, for example, Isalou, Zamani, Shahmoradi and Alizadeh (2012) attempted to locate a suitable place to dispose the municipal solid wastes hygienically in Kahak town, Qom, Iran. They designed a model that can be applied in site selection for solid waste landfill by using fuzzy logic and analysis network process (ANP).

Kirimi and Waithaka (2014) developed landfill site selection method by employing GIS and AHP technique for evaluating the suitability for landfill site selection in Nakuru town in Kenya. Through integrating GIS with AHP, a final suitability map was drawn with eleven candidate sites ranked from the most to the least suitable site. 
Rahmat et al. (2016) used GIS and AHP technique to select the suitable solid waste landfill site for Behbahan, Iran. They used SAW method to evaluate landfill suitability index. The results showed that five sites within the region under study were suitable for landfilling.

This study aims at designing a model to determine the optimal solid waste landfill site using GIS and AHP technique at west side of Mosul city.

\section{Materials and methods}

\section{Study area}

The study area is located at west side of Mosul city. The study area contains different agricultural and industrial sites surrounding the outer municipal boundary of city center. It lies approximately between longitudes 42 $52^{\prime} 54^{\prime \prime} \mathrm{E}$ and $43^{\circ} 11^{\prime} 51^{\prime \prime} \mathrm{E}$, while latitudes $36^{\circ} 11^{\prime} 57^{\prime \prime} \mathrm{N}$ and $36^{\circ} 24^{\prime} 21^{\prime \prime} \mathrm{N}$. Total study area is $1,646 \mathrm{~km}^{2}$ as in Figure 1.

\section{Data analysis}

A group of base maps including satellite imagery and district maps are utilized to derive the used variables. A number of tabulated and statistical data are used such as climate, population and groundwater data. A database is built utilizing the used variables with input map data as in Table 1.

The studied data can be classified according to specified processing method into two types: the first type is discrete data which includes the following variables (transportation routes, airport, residential sections, pipelines, power lines, river, villages, military base), as in Figure 2. The second type is continuous data which includes certain variables (soil, geological information, land use, slope, topography, groundwater depth, wind direction), as in Figure 3.

TABLE 1. Input map data

\begin{tabular}{|c|l|l|}
\hline No & \multicolumn{1}{|c|}{ Data } & \multicolumn{1}{c|}{ Objects } \\
\hline 1 & $\begin{array}{l}\text { WorldView-2 satellite image gallery high-resolution } \\
30 \mathrm{~cm} \text {, for Mosul city, 2016 }\end{array}$ & Roads and power lines \\
\hline 2 & $\begin{array}{l}\text { Topographic maps scale } 1: 100000 \text { for Mosul, Iraq, } \\
1989\end{array}$ & Villages, pipelines \\
\hline 3 & Landsat 7, ETM+, raw path (170, 35), 2014 & Land use \\
\hline 4 & Residential sections map of Mosul city, 2012 & Residential sections \\
\hline 5 & Districts map of Mosul (the agricultural districts), 2009 & Location \\
\hline 6 & Geological map ( Mosul), scale 1 : 250 000, 1995 & Geological \\
\hline 7 & $\begin{array}{l}\text { Soil condition in Iraq, Ministry of Agriculture } \\
\text { (Buringh, 1961) }\end{array}$ & Soil \\
\hline 8 & $\begin{array}{l}\text { Raster Dem 30 m ASTGTM_N36E043, } \\
\text { ASTGTM_N36E042 }\end{array}$ & Slope, elevation, stream \\
\hline 9 & Data of meteorological stations - Iraq, 1992-2012 & Wind direction \\
\hline 10 & Wells data - Iraq, 2014 & Groundwater depth and wells locations \\
\hline 11 & Iraqi Ministry of Planning, 2007 & Statistical data \\
\hline
\end{tabular}



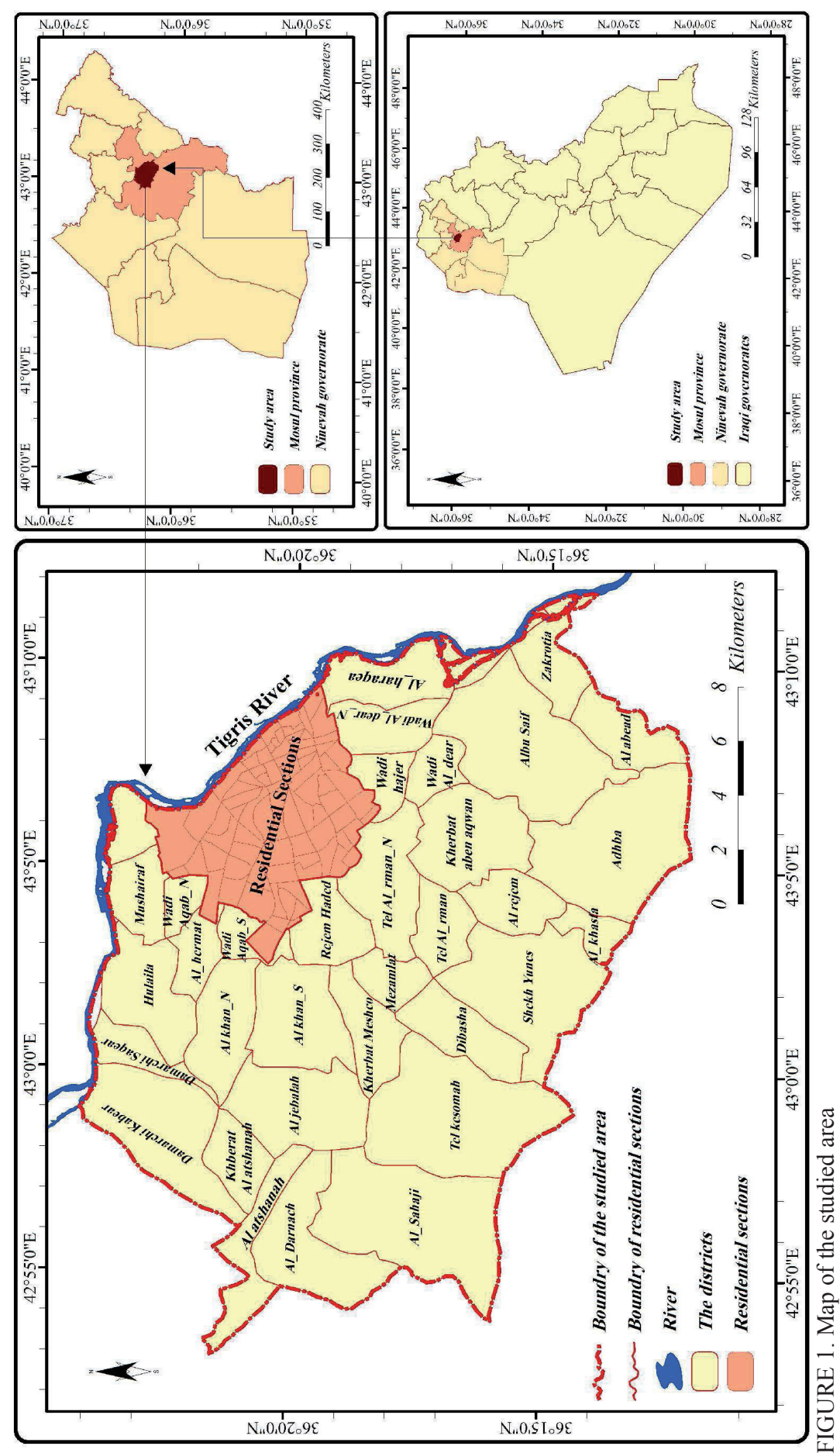


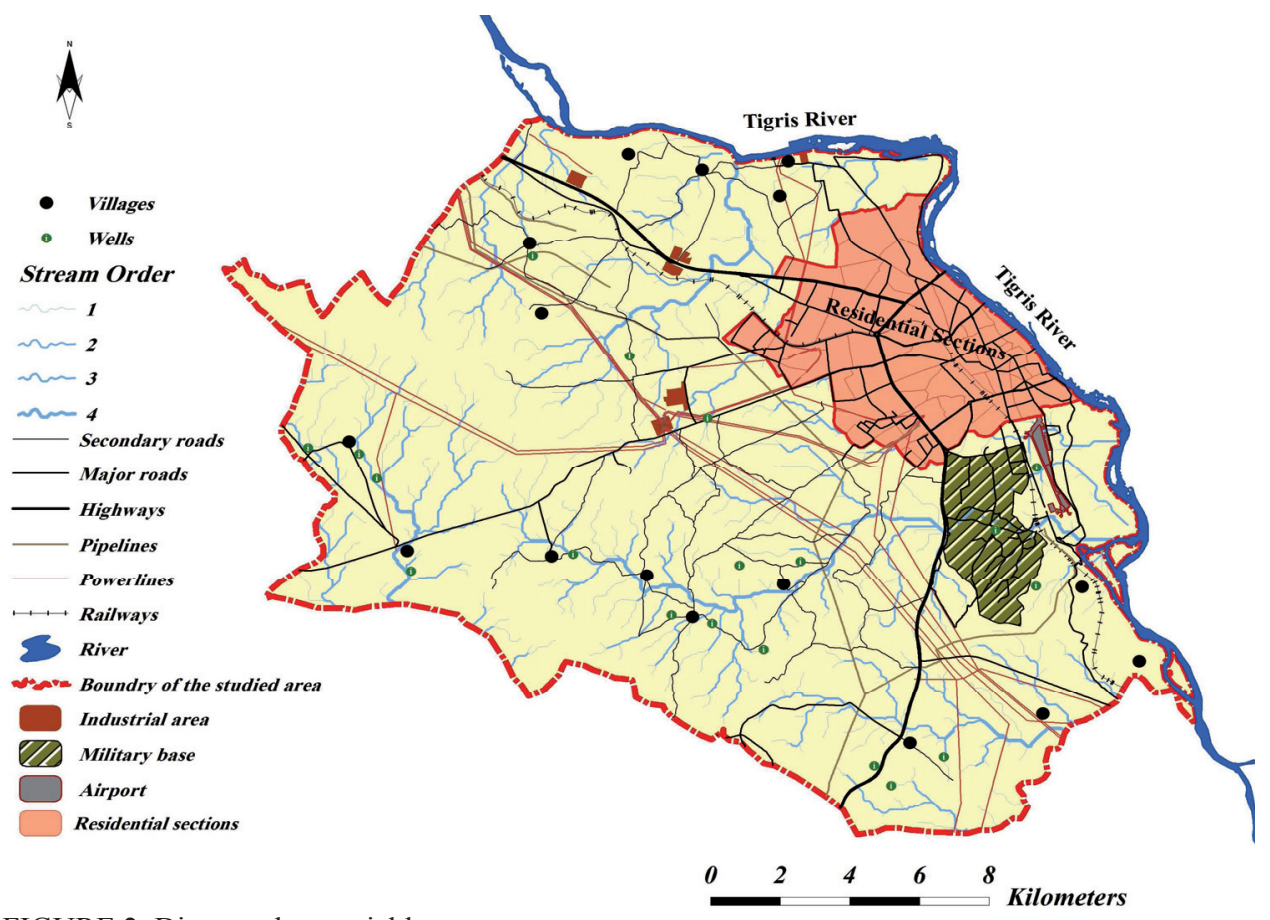

FIGURE 2. Discrete data variables map

\section{Methodology}

\section{Geographic information system (GIS)}

ARC GIS 10.2.2 software was is used in this study to create a proper model through applying multiple variables.

\section{Analytical hierarchical process (AHP)}

The AHP is a technique used to derive priority weights through pair wise comparisons (Saaty, 1980, 2008). The AHP has been used on three main stages. Firstly, developing a systematic hierarchy of extracted variables. Secondly, the compared pair wise matrix is applied by setting the variables, and these variables are analyzed to develop a series of relative weights, as in Table 2. Finally, the consistency ratio (CR) is calculated to determine the accuracy of weighting. In case of the
CR's value is $\leq 0.1$, the weighting is accurate; if not, the variables' relative weights must be re-weighted. Pair wise comparison matrix for selecting variables and its CR is listed in Table 3. Super Decision SD software 20.8 is an extension of AHP

TABLE 2. Scale of relative importance for pair wise comparison (Satty, 1980, 2008)

\begin{tabular}{|c|c|}
\hline $\begin{array}{c}\text { im- } \\
\text { por- } \\
\text { tance }\end{array}$ & Definition \\
\hline 1 & equal importance \\
\hline 2 & equal to moderately importance \\
\hline 3 & moderate importance \\
\hline 4 & moderate to strong importance \\
\hline 5 & strong importance \\
\hline 6 & strong to very strong importance \\
\hline 7 & very strong importance \\
\hline 8 & very to extremely strong importance \\
\hline 9 & extreme importance \\
\hline
\end{tabular}



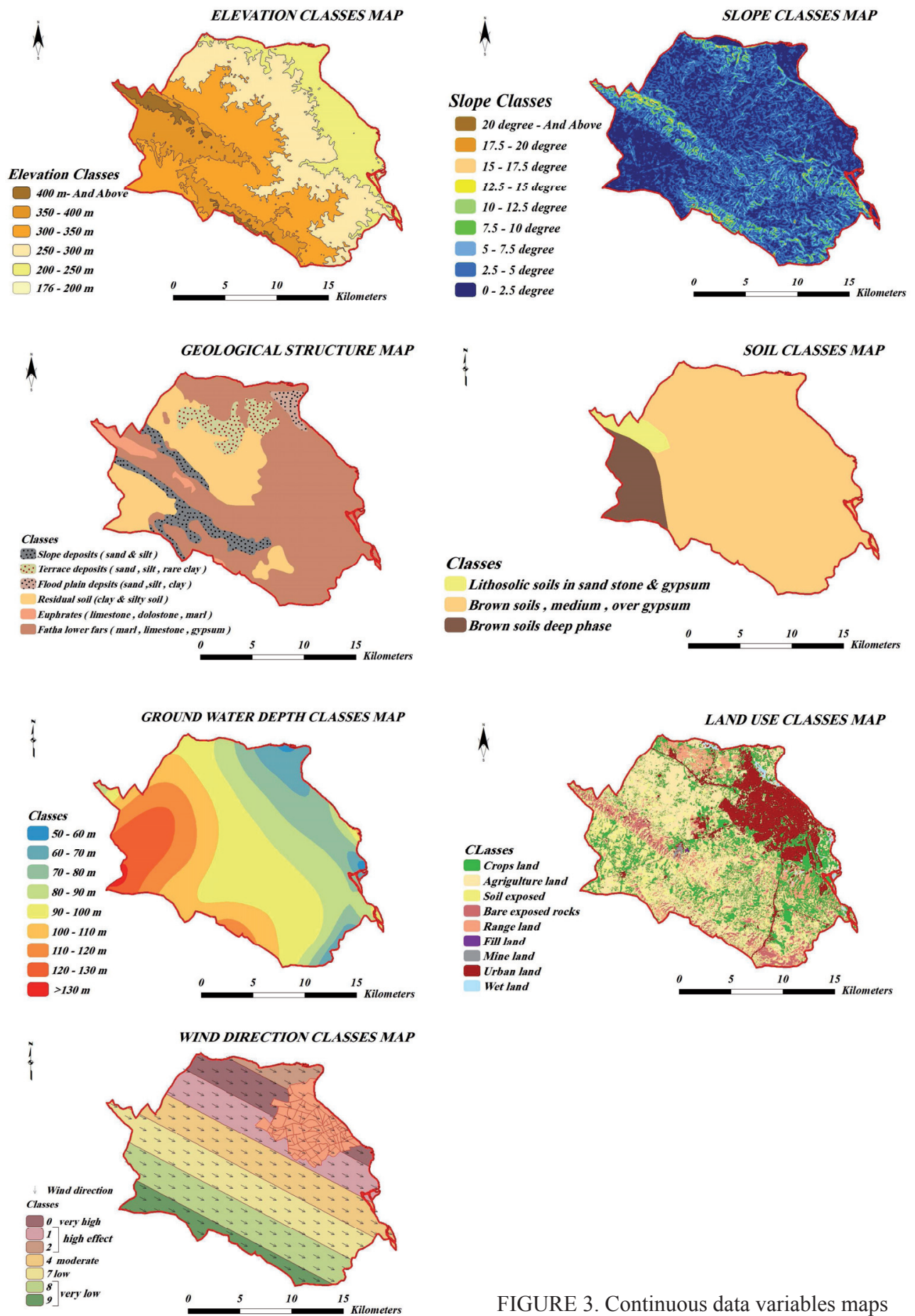

FIGURE 3. Continuous data variables maps 
technique used to simplify the weight calculations, as in Table 4. This extension has the ability to analyze a problem into its elements (Kirytopoulos, Voulgaridou \& Rokou, 2011).

\section{Landfill required area}

It is necessary to have a sufficient landfill area to cover the total solid waste enough for at least five years (Tchoba- noglous, Theisen \& Eliassen, 2007). Therefore, it is obligatory to have an estimation of the expected future population increasing rate and the average daily solid waste generation. The following formula is used to estimate the population of west side of Mosul city in 2017 based on the reference data taken from (Iraqi Ministry of Planning, 2007): $P_{f}=$ $=P_{o}(1+r)^{n}$, where: $n$ is number of years; $P_{o}$ is population in 2007 which was estimated as 423,241 citizens; $P_{f}$ is popula-

TABLE 3. Pair wise comparison matrix for selecting suitable landfill site

\begin{tabular}{|c|c|c|c|c|c|c|c|c|c|c|c|c|c|c|c|c|c|c|c|c|c|}
\hline$\frac{n}{3}$ & 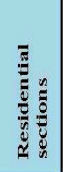 & 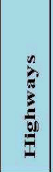 & 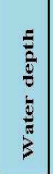 & 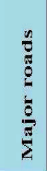 & 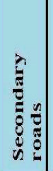 & שू & $\frac{d}{\partial}$ & 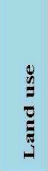 & $\frac{n}{\tilde{E}}$ & $\frac{\bar{\alpha}}{\bar{\alpha}}$ & $\begin{array}{l}n \\
\overline{0} \\
\bar{z}\end{array}$ & $\frac{\stackrel{0}{\sigma}}{\frac{\sigma}{v}}$ & 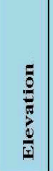 & 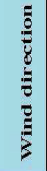 & $\overline{\overline{3}}$ & $\begin{array}{c}\bar{\sigma} \\
\overline{0} \\
\overline{0} \\
\frac{8}{8} \\
8 \\
\delta\end{array}$ & 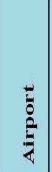 & 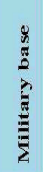 & 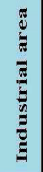 & 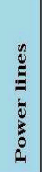 & 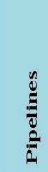 \\
\hline Residential sections & 1 & 2 & 3 & 3 & $?$ & 9 & 6 & 2 & 5 & 6 & 6 & 2 & 5 & 2 & 3 & 3 & 6 & 9 & 9 & 8 & 6 \\
\hline Highways & 0.5 & 1 & 2 & 2 & 4 & 7 & 3 & 0.5 & 3 & 2 & 3 & 1 & 2 & 1 & 1 & 2 & 3 & 7 & 7 & 8 & 4 \\
\hline Water depth & 0.33 & 0.5 & 1 & 1 & 3 & 5 & 2 & 5 & 2 & 3 & 3 & 0.5 & 3 & 1 & 1 & 2 & 2 & 5 & 6 & 4 & 3 \\
\hline Major roads & 0.33 & 0.5 & 1 & 1 & 3 & 5 & 2 & 0.33 & 2 & 2 & 3 & 0.5 & 2 & 0.5 & 1 & 1 & 2 & 5 & 6 & 4 & 3 \\
\hline Secondary roads & 0.142 & 0.25 & 0.33 & 0.33 & 1 & 2 & 1 & 0.12 & 0.5 & 0.5 & 1 & 0.2 & 0.5 & 0.25 & 0.33 & 0.5 & 1 & 2 & 3 & 2 & 0.5 \\
\hline Railway & 0.111 & 0.14 & 0.2 & 0.2 & 0.5 & 1 & 0.33 & 0.11 & 0.33 & 0.5 & 0.5 & 0.11 & 0.33 & 0.14 & 0.16 & 0.2 & 0.33 & 1 & 1 & 1 & 0,333 \\
\hline Villages & 0.167 & 0.33 & 0.5 & 0.5 & 1 & 3 & 1 & 0.2 & 1 & 1 & 2 & 0.33 & 1 & 0.33 & 0.5 & 0.5 & 1 & 3 & 3 & 2 & 1 \\
\hline Land use & 0.5 & 2 & 2 & 3 & 8 & 9 & 5 & 1 & 5 & 6 & 6 & 2 & 4 & 2 & 2 & 3 & 4 & 9 & 9 & 9 & 6 \\
\hline Streams & 0.2 & 0.33 & 0.5 & 0.5 & 2 & 3 & 1 & 0.2 & 1 & 1 & 2 & 0.33 & 1 & 0.33 & 0.5 & 0.5 & 1 & 3 & 4 & 3 & 2 \\
\hline River & 0.167 & 0.5 & 0.33 & 0.5 & 2 & 2 & 1 & 0.16 & 1 & 1 & 2 & 0.33 & 1 & 0.33 & 0.5 & 0.5 & 1 & 3 & 4 & 3 & 2 \\
\hline Wells & 0.167 & 0.33 & 0.33 & 0.33 & 1 & 2 & 0.5 & 0.16 & 0.5 & 0.5 & 1 & 0.2 & 0.5 & 0.25 & 0.33 & 0.33 & 0.5 & 2 & 3 & 2 & 1 \\
\hline Slope & 0.5 & 1 & 2 & 2 & 5 & 9 & 3 & 0.5 & 3 & 3 & 5 & 1 & 3 & 1 & 2 & 2 & 3 & 9 & 9 & 8 & 5 \\
\hline Elevation & 0.2 & 0.5 & 0.33 & 0.5 & 2 & 3 & 1 & 0.25 & 1 & 1 & 2 & 0.33 & 1 & 0.33 & 0.33 & 0.5 & 1 & 3 & 4 & 2 & 1 \\
\hline Wind direction & 0.5 & 1 & 1 & 2 & 4 & 7 & 3 & 0.5 & 3 & 3 & 4 & 1 & 3 & 1 & 1 & 2 & 3 & 7 & 8 & 6 & 4 \\
\hline Soil & 0.33 & 1 & 1 & 1 & 3 & 6 & 2 & 0.5 & 2 & 2 & 3 & 0.5 & 3 & 1 & 1 & 2 & 2 & 6 & 6 & 5 & 2 \\
\hline Geological & 0.33 & 0.5 & 0.5 & 1 & 2 & 5 & 2 & 0.33 & 2 & 2 & 3 & 0.5 & 2 & 0.5 & 0.5 & 1 & 2 & 5 & 5 & 5 & 2 \\
\hline Airport & 0.167 & 0.33 & 0.5 & 0.5 & 1 & 3 & 1 & 0.25 & 1 & 1 & 2 & 0.33 & 1 & 0.33 & 0.5 & 0.5 & 1 & 3 & 3 & 2 & 1 \\
\hline Military base & 0.111 & 0.14 & 0.2 & 0.2 & 0.5 & 1 & 0.33 & 0.11 & 0.33 & 0.33 & 0.5 & 0.11 & 0.33 & 0.14 & 0.16 & 0.2 & 0.33 & 1 & 1 & 0.5 & 0.33 \\
\hline Industrial area & 0.11 & 0.14 & 0.16 & 0.16 & 0.33 & 1 & 0.33 & 0.11 & 0.25 & 0.25 & 0.33 & 0.11 & 0.25 & 0.12 & 0.16 & 0.2 & 0.33 & 1 & 1 & 0.5 & 0.33 \\
\hline Power lines & 0.125 & 0.12 & 0.25 & 0.25 & 0.5 & 1 & 0.5 & 0.11 & 0.33 & 0.33 & 0.5 & 0.12 & 0.5 & 0.16 & 0.2 & 0.2 & 0.5 & 2 & 2 & 1 & 0.5 \\
\hline Pipelines & 0.167 & 0.25 & 0.33 & 0.33 & 2 & 3 & 1 & 0.16 & 0.5 & 0.5 & 1 & 0.2 & 1 & 0.25 & 0.5 & 0.5 & 1 & 3 & 3 & 2 & 1 \\
\hline
\end{tabular}

Consistency ratio $=0.01057$. 
TABLE 4. Variable buffer zones (Iraqi Environmental Legislation, 2011) and AHP extracted weights

\begin{tabular}{|c|c|c|c|c|c|c|c|c|c|}
\hline No & Variable & Buffer zones & $R$ & $\begin{array}{c}\text { AHP } \\
\text { weight }\end{array}$ & No & Variable & Buffer zones & $R$ & $\begin{array}{c}\text { AHP } \\
\text { weight }\end{array}$ \\
\hline \multirow{7}{*}{1} & \multirow{7}{*}{$\begin{array}{l}\text { Residential } \\
\text { distance }\end{array}$} & $0-4000 \mathrm{~m}$ & 0 & \multirow{7}{*}{0.147369} & \multirow{2}{*}{9} & \multirow{2}{*}{ Streams } & $0-350 \mathrm{~m}$ & 0 & \multirow{2}{*}{0.030793} \\
\hline & & $4000-5000 \mathrm{~m}$ & 9 & & & & $>350 \mathrm{~m}$ & 9 & \\
\hline & & $5000-6000 \mathrm{~m}$ & 8 & & \multirow{2}{*}{10} & \multirow{2}{*}{ River } & 0-2000 m & 0 & \multirow{2}{*}{0.030006} \\
\hline & & $6000-7000 \mathrm{~m}$ & 7 & & & & $>2000 \mathrm{~m}$ & 9 & \\
\hline & & $7000-8000 \mathrm{~m}$ & 6 & & \multirow{2}{*}{11} & \multirow{2}{*}{ Wells } & 0-350 m & 0 & \multirow{2}{*}{0.019411} \\
\hline & & $8000-9000 \mathrm{~m}$ & 5 & & & & $>350 \mathrm{~m}$ & 9 & \\
\hline & & $9000-10000 \mathrm{~m}$ & 4 & & \multirow{9}{*}{12} & \multirow{9}{*}{ Slope } & $0-2.5^{\circ}$ & 9 & \multirow{9}{*}{0.091454} \\
\hline \multirow{5}{*}{2} & \multirow{5}{*}{ Highways } & $0-1000 \mathrm{~m}$ & 0 & \multirow{5}{*}{0.079151} & & & $2.5-5^{\circ}$ & 7 & \\
\hline & & $1000-2000 \mathrm{~m}$ & 9 & & & & $5-7.5^{\circ}$ & 6 & \\
\hline & & $2000-3000 \mathrm{~m}$ & 6 & & & & $7.5-10^{\circ}$ & 4 & \\
\hline & & $3000-4000 \mathrm{~m}$ & 3 & & & & $10-12.5^{\circ}$ & 3 & \\
\hline & & $>4000 \mathrm{~m}$ & 1 & & & & $12.5-15^{\circ}$ & 2 & \\
\hline \multirow{9}{*}{3} & \multirow{9}{*}{$\begin{array}{l}\text { Water } \\
\text { depth }\end{array}$} & $50-60 \mathrm{~m}$ & 1 & \multirow{9}{*}{0.06065} & & & $>15^{\circ}$ & 0 & \\
\hline & & $70-60 \mathrm{~m}$ & 2 & & & & $0-2.5^{\circ}$ & 9 & \\
\hline & & $80-70 \mathrm{~m}$ & 3 & & & & $2.5-5^{\circ}$ & 7 & \\
\hline & & $90-80 \mathrm{~m}$ & 4 & & \multirow{6}{*}{13} & \multirow{6}{*}{ Elevation } & $176-200 \mathrm{~m}$ & 9 & \multirow{6}{*}{0.029048} \\
\hline & & $100-90 \mathrm{~m}$ & 5 & & & & $200-250 \mathrm{~m}$ & 7 & \\
\hline & & $110-100 \mathrm{~m}$ & 6 & & & & $250-300 \mathrm{~m}$ & 6 & \\
\hline & & $120-110 \mathrm{~m}$ & 7 & & & & $300-350 \mathrm{~m}$ & 4 & \\
\hline & & $130-120 \mathrm{~m}$ & 8 & & & & $350-400 \mathrm{~m}$ & 2 & \\
\hline & & $>130 \mathrm{~m}$ & 9 & & & & $400-485 \mathrm{~m}$ & 0 & \\
\hline \multirow{6}{*}{4} & \multirow{6}{*}{$\begin{array}{c}\text { Major } \\
\text { roads } \\
(\mathrm{R} 1)\end{array}$} & $0-500 \mathrm{~m}$ & 0 & & & & High effect & 2 & \\
\hline & & 500-1000 m & 9 & & 14 & Wind & Middle effect & 4 & 0.079223 \\
\hline & & $1000-1500 \mathrm{~m}$ & 7 & e520 & & & Middle effect & 5 & \\
\hline & & $1500-2000 \mathrm{~m}$ & 5 & 0.0528 & & & $\mathrm{~S} 1$ & 5 & \\
\hline & & $2000-2500 \mathrm{~m}$ & 3 & & 15 & Soil & $\mathrm{S} 2$ & 7 & 0.061559 \\
\hline & & $>2500 \mathrm{~m}$ & 2 & & & & $\mathrm{~S} 3$ & 9 & \\
\hline & & $0-100 \mathrm{~m}$ & 0 & & & & G1 & 2 & \\
\hline & & $100-200 \mathrm{~m}$ & 9 & & & & G2 & 9 & 0.048073 \\
\hline 5 & Secondary & $200-300 \mathrm{~m}$ & 7 & 0 & 16 & Geological & G3 & 4 & \\
\hline 5 & roads (R2) & $300-400 \mathrm{~m}$ & 5 & 0.019198 & & & G4 & 6 & \\
\hline & & $400-500 \mathrm{~m}$ & 3 & & 17 & Airnort & $0-1500 \mathrm{~m}$ & 0 & 0027795 \\
\hline & & $>500 \mathrm{~m}$ & 2 & & 17 & Alrport & $>1500 \mathrm{~m}$ & 9 & $0.02 / 195$ \\
\hline 6 & & $0-500 \mathrm{~m}$ & 0 & & 18 & Military & $0-1000 \mathrm{~m}$ & 0 & \\
\hline 6 & $\mathrm{~K}$ & $>500 \mathrm{~m}$ & 9 & $0.010 / 36$ & 18 & base & $>1000 \mathrm{~m}$ & 9 & \\
\hline
\end{tabular}


TABLE 4, cont.

\begin{tabular}{|c|c|c|c|c|c|c|c|c|c|}
\hline No & Variable & Buffer zones & $R$ & $\begin{array}{c}\text { AHP } \\
\text { weight }\end{array}$ & No & Variable & Buffer zones & $R$ & $\begin{array}{c}\text { AHP } \\
\text { weight }\end{array}$ \\
\hline \multirow{2}{*}{7} & \multirow{2}{*}{ Villages } & $0-1000 \mathrm{~m}$ & 0 & \multirow{2}{*}{0.02753} & \multirow[b]{2}{*}{19} & \multirow{2}{*}{$\begin{array}{c}\text { Industrial } \\
\text { area }\end{array}$} & $0-500 \mathrm{~m}$ & 0 & \multirow{2}{*}{0.009306} \\
\hline & & $>1000 \mathrm{~m}$ & 9 & & & & $>500 \mathrm{~m}$ & 9 & \\
\hline \multirow{6}{*}{8} & \multirow{6}{*}{ Land use } & Urban & 0 & \multirow{6}{*}{0.128512} & \multirow[b]{2}{*}{20} & \multirow{2}{*}{$\begin{array}{c}\text { Power } \\
\text { lines }\end{array}$} & $0-100 \mathrm{~m}$ & 0 & \multirow{2}{*}{0.012792} \\
\hline & & Mine land & 0 & & & & $>100 \mathrm{~m}$ & 9 & \\
\hline & & Crops & 4 & & \multirow[b]{2}{*}{21} & \multirow[b]{2}{*}{ Pipe lines } & $0-100 \mathrm{~m}$ & 0 & \multirow[b]{2}{*}{0.023826} \\
\hline & & $\begin{array}{l}\text { Agriculture } \\
\text { land }\end{array}$ & 5 & & & & $>100 \mathrm{~m}$ & 9 & \\
\hline & & Range land & 7 & & \multirow{2}{*}{\multicolumn{5}{|c|}{$x$}} \\
\hline & & $\begin{array}{c}\text { Bare exposed } \\
\text { rocks }\end{array}$ & 9 & & & & & & \\
\hline
\end{tabular}

S1 - Lithosolic Soils in Sand Stone \& Gypsum, S2 - Brown Soils, Medium, over Gypsum, S3 - Brown Soils Deep Phase, G1 - Slope Deposits \& Terrace Deposits, G2 - Residual Soil (Clay \& Silt), G3 - Fatha Lower Fares (Marl, Limestone, Gypsum), G4 - Euphrates (Limestone, Dolostone, Marl).

tion in 2017, population growth rate $(r)$ was (3.2\%), based on estimates of Directorate of Municipal in Nineveh (2009). The population number is 579,943 citizens in 2017.

The yearly accumulative weight of solid waste is calculated based on the population $(579,943$ citizens) multiplied by solid waste generation (0.61 $\mathrm{kg} \cdot$ capita $\left.^{-1} \cdot \mathrm{day}^{-1}\right)$ (Al-Rawi \& Al-Tayar, 2012). The compacted density of solid waste in landfill is $450 \mathrm{~kg} \cdot \mathrm{m}^{-3}$ (Al-Anbari, Kadum \& Taha 2008).

The yearly accumulative volume of solid waste is calculated by dividing the total weight by compacted solid waste density. The resulted calculated area is extracted by dividing the total accumulative volume by the depth lift $(3 \mathrm{~m})$. Then, the required area is computed by multiplying the calculated area by 1.4 factor (Tchobanoglous et al., 2007). The final required area is $133,907 \mathrm{~m}^{2}$ for one year. For five years the required area is $669,535 \mathrm{~m}^{2}$.

\section{Drawing the ranking and final map}

Based on the collected data, buffer zones of each variable are derived and then converted into a thematic map. The ranking map has been created after multiplying each variable with its extracted weight. The degree of suitability for the ranking map is divided into a number of ranks according to the relative importance to the candidate sites starting from the least importance to the highest importance, as in Figure 4. The final map has been created by converting the highest value obtained from the ranking map from raster to vector format and calculating the optimal landfill site area, as in Figure 5.

\section{Model building}

The model has been built through applying ArcGIS 10.2.2 software tools. These tools are arranged as follows: ras- 


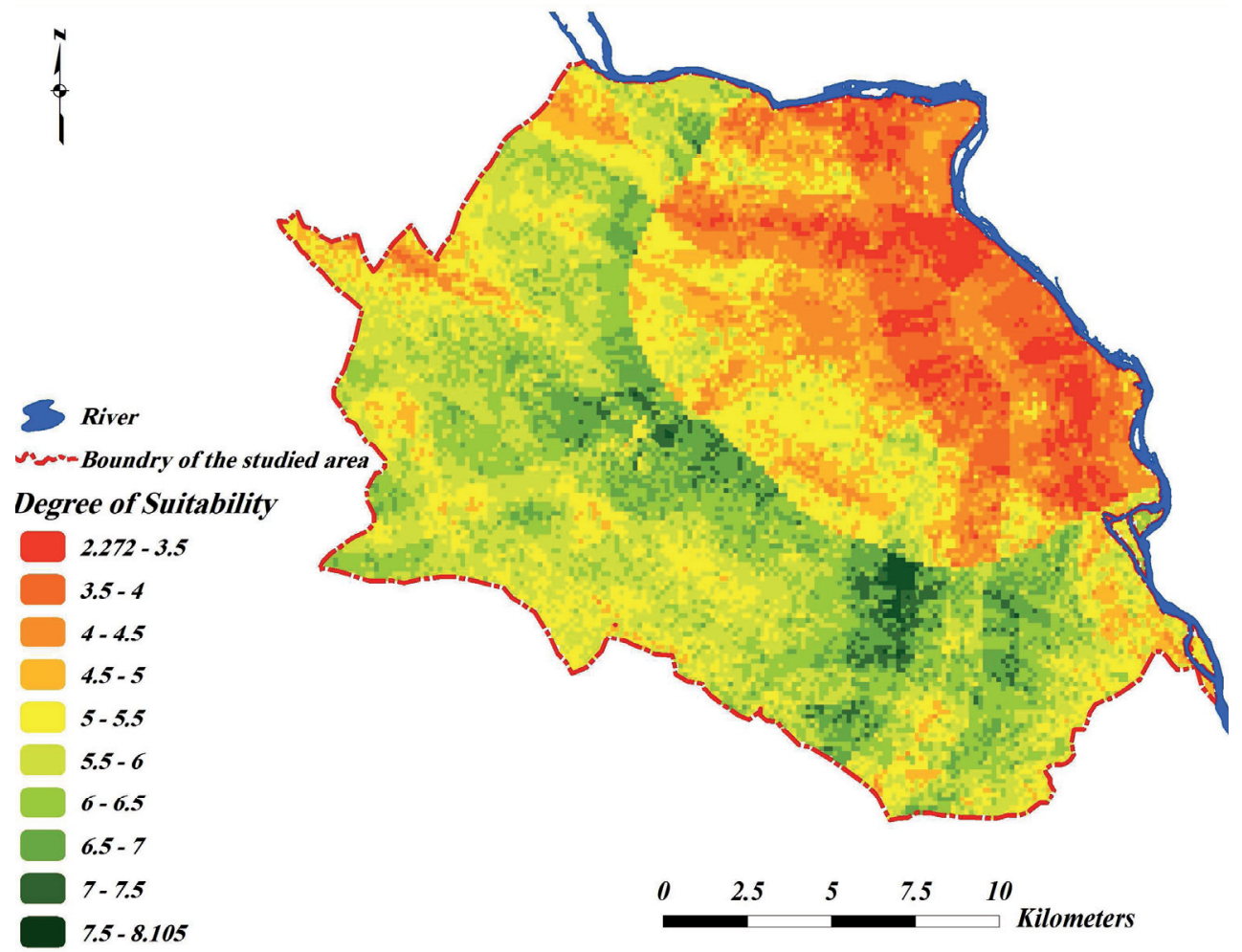

FIGURE 4. Ranking of weighted variables map

terization converts the vector format to raster format. Euclidean distance gives the distance for discrete data from each cell in the raster to the closest source, noting that this tool is only used with raster format. Reclassification tool is used to reclassify each variable into classes according to environmental standard scale which produces a new layer, and this layer can be used to generate data to be processed by map algebra. Raster calculator is used to perform geographic analysis as raster data processed in Arc GIS 10.2.2. Other supporting tools are used to derive a number of variables such as (hydrology tools analysis and geostastical analysis) to generate wind directions and underground water depth, as in Figure 6.

\section{Results}

According to Iraqi Environmental Legislation (2011) accompanied with economical factors, a variety of variables have been used with their extracted weights for landfill sites. The most important variables are the distance to residential sections, the group of transportation roads and land use, come in the first order. A group of variables with medium importance come in the second order, such as slope, groundwater depth, soil 


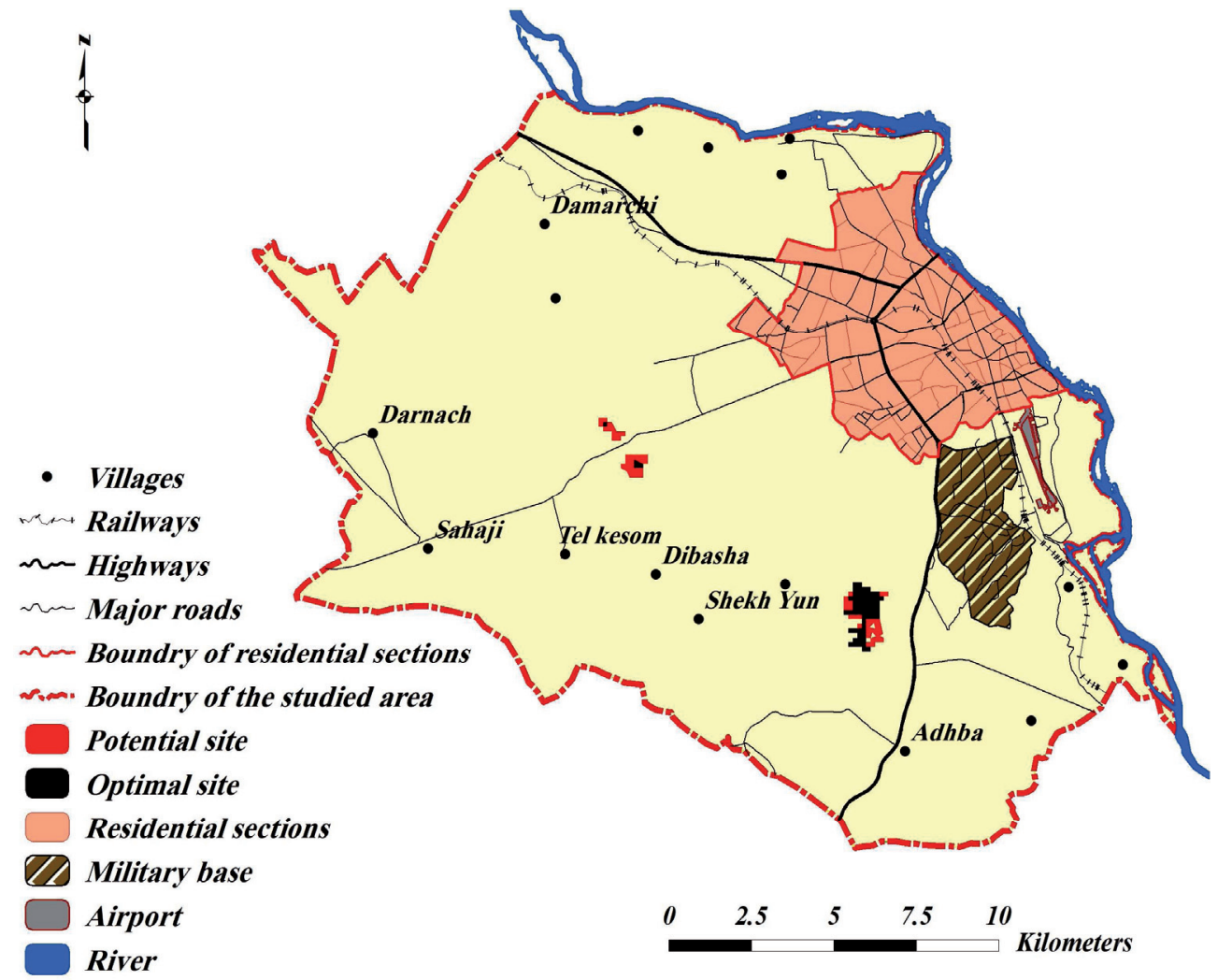

FIGURE 5. The final map

type and geological structure. The rest of the variables take the lowest order.

The study is based on building a model using GIS and AHP technique to extract the weights through applying Super Decision SD software to draw the final map for the optimal landfill site. The optimal site is situated to the south-west of the west side of Mosul city with longitude as $43^{\circ} 5^{\prime} 25^{\prime \prime}$ and latitude as $36^{\circ} 15^{\prime}$ $52^{\prime \prime}$, and the total area is $1,114,303 \mathrm{~m}^{2}$. While the other site comes in the second rank, noting that it consists of two sections, the first section surrounds the first site $\left(531,652 \mathrm{~m}^{2}\right)$ which is sufficient for extra future four years of expansion, and the second section is located at the west of the city with longitude as $43^{\circ} 0^{\prime} 43^{\prime \prime}$ and latitude as $36^{\circ} 8^{\prime} 12^{\prime \prime}$ with an area of $408,159 \mathrm{~m}^{2}$ and sufficient for future three years of expansion. The second section is useful for future expansion plans for the optimal site, and it is near the current dumping site.

\section{Conclusions}

This study attempts to locate the optimal solid waste landfill site in the west side of Mosul city. A number of variables are 


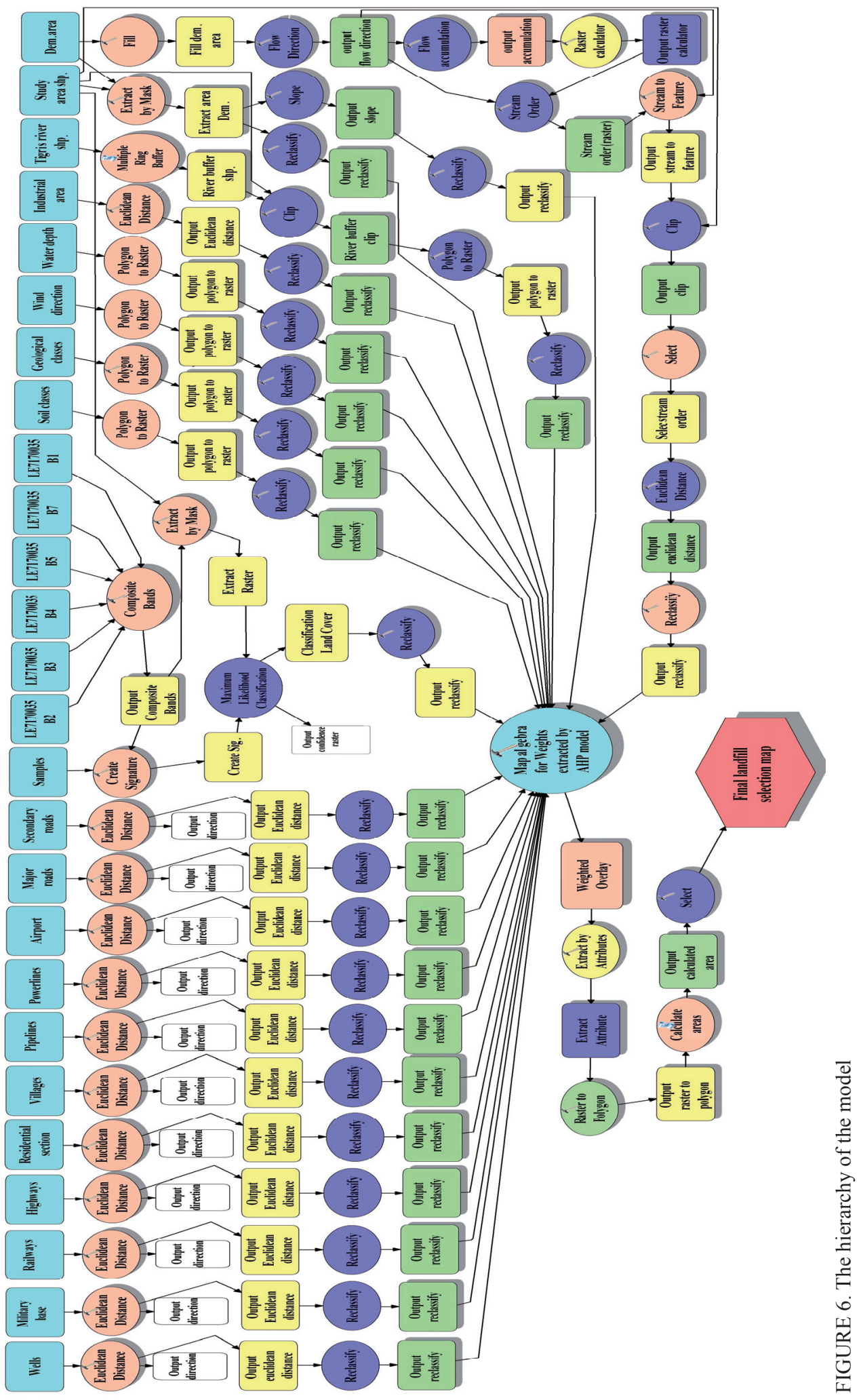


used and obtained in GIS. AHP technique is used to determine the relative weights of variables. The results show that among the studied variables, the distance to residential sections, the group of transportation roads and land use are the most essential variables. The optimal site has an area of $1,114,303 \mathrm{~m}^{2}$ and is sufficient for eight years and enough for one lift.

\section{References}

Al-Rawi, S. \& Al-Tayar, T.A. (2012). Productivity structure of solid waste at Mosul city: a comparison between two decades. Tikrit Journal of Engineering Sciences, 19(1), 25-43.

Al-Anbari, M.A., Kadum, N. \& Taha, L. (2008). Assessment of the Solid Waste Volume for the Year 2006 in Hilla City and the Required Environmental Management Policies. Kufa University Journal, 10, 109-128.

Buringh, P. (1960). Soil and soil conditions in Iraq. Iraq: Iraqi Ministry of Agriculture.

Chabuk, A.J., Al-Ansari, N. Hassain M.H. \& Knutsson, S. (2017). GIS-based assessment of combined AHP and SAW methods for selecting suitable sites for landfill in AL-MusayiabQadhaa, Babylon-Iraq. Environment Earth Science, 76, 209. DOI 10.1007/ /122665-017-6524-X

Directorate of Agriculture in Nineveh (2009). District cartographic map of Mosul province, scale 1:20000 (feedback documentation).

Directorate of Municipal in Nineveh (2009). Planning and information department. Population data for residential areas for Mosul city (feedback documentation).

Directorate of Municipal in Mosul (2012). Urban planning department. Map of Mosul city, scale 1 : 5000 (feedback documentation).

Geological map of Mosul (1995). Quadrangle sheet $N J-38-13$, scale $1: 250$ 000. Iraq: State Establishment of Geological Survey and Mining.

Iraqi Directorate of Underground Water (2014). Wells data of north Iraq (feedback documentation).

Iraqi Environmental Legislation (2011). Ministry of Justice, 4225.
Iraqi Metrological Organization and Seismology (2014). Data of Meteorological Stations Northern of Iraq from 1992 to 2012. Iraqi Ministry of Transportation, Department of Climate (feedback documentation).

Iraqi Ministry of Planning (2007). Annual statistical group for population growth percentage for 2007. Annual Statistical Group (feedback documentation).

Isalou, A.A., Zamani, V., Shahmoradi, B. \& Alizadeh, H. (2012). Landfill Site Selection Using Integrated Fuzzy Logic and Analytic Network Process F-ANP. Environmental Earth Sciences, 68(6), 1745-1755. DOI 10.1007/s12665-012-1865-y

Kirimi, F.K. \& Waithaka, E.H. (2014). Determination of Suitable Landfill Site Using Geospatial Techniques and Multi-Criteria Decision Analysis: A Case Study of Nakuru Town, Kenya. International Journal of Science and Research, 3(11), 2319-7064.

Kirytopoulos, K., Voulgaridou, D. \& Rokou, E. (2011). ANP Solver, Alternative Tool for Implementing ANP Method. International Journal of Applied Decision Sciences, 4(1), 34-56.

Landsat 7, ETM+,Warspath $(170,35)$, A causations date (2014). Earth Explore USGS . Retrieved from: https://earthexplorer.usgs.gov.

Raster Global Digital Elevation Model (ASTGTM N36E042, ASTGTM N36E043).

Rahmat, Z.G, Niri, M.V., Alavi, N. Goudarzi, G. Babaei, A.A., Baboli, Z., \& Hosseinzadeh, M. (2016). Landfill Site Selection Using GIS and AHP: A Case Study: Behbahan, Iran. KSCE Journal of Civil Engineering, 21(1), 111-118. DOI 10.1007/s12205-016-0296-9

Saaty, T.L. (1980). The Analytic Hierarchy Process. New York: McGraw-Hill.

Saaty, T.L. (2008). Decision Making with the Analytic Hierarchy Process. International Journal of Sciences, 1(1), 83-98.

Tchobanoglous, G., Theisen, H., Eliassen, R. (2007). Solid Wastes Engineering Principles and Management Issues. New York: McGraw-Hill.

Topographic map of Iraq (1989). Iraqi Air Force Surveying Maps for Mosul (J-38-T-SW), scale $1: 100000$.

WorldView-2 Satellite Image Gallery HighResolution $30 \mathrm{~cm}$ (2016). Retrieved from: https://www.satimagingcorp.com/satellitesensors/worldview-2/. 


\section{Summary}

GIS and AHP based modeling for landfill site selection (case study: west side of Mosul city). The accumulation of large quantities of solid waste inside Mosul city becomes a real residential and municipal management problem. There are many reasons including the existence of unplanned dumping sites within the city boundaries, and the absence of scientific researches which applies modern techniques for selecting the optimal solid waste landfill. This study uses geographic information system (GIS) and analytic hierarchical process (AHP) which is used to extract the weights with the help of Super Decision SD software. The studied variables data can be classified according to specified processing method into two types: continuous data, and discrete data. The ranking map has been designed after multiplying each variable with its extracted weight, then the final map has been created based on the values obtained from the ranking map. The results show that the optimal landfill area is located at south west Mosul city. This study aims at building a model by using GIS to determine the optimal and potential solid waste landfill site.

\section{Authors' address:}

Raid Mahmood Faisal Al-Moula

Mohammed Fakhraldeen Ahmed

Mosul University - IRAQ

College of Environmental Sciences and Technology

e-mail: raidalfaisal2017@yahoo.com mfakher1962@gmail.com 